\title{
Proceedings of the Yorkshire Geological Society
}

\author{
Middle Telychian (Llandovery, Silurian) graptolites and \\ biostratigraphy of the Howgill Fells, England, based upon the \\ collections of D.W.R. Wilson housed in the Lapworth \\ Museum of Geology, University of Birmingham
}

\section{David K. Loydell}

DOI: https://doi.org/10.1144/pygs2019-014

Received 13 August 2019

Revised 13 February 2020

Accepted 13 February 2020

(C) 2020 The Author(s). Published by The Geological Society of London for the Yorkshire Geological Society. All rights reserved. For permissions: http://www.geolsoc.org.uk/permissions. Publishing disclaimer: www.geolsoc.org.uk/pub_ethics

To cite this article, please follow the guidance at https://www.geolsoc.org.uk/ /media/Files/GSL/shared/pdfs/Publications/AuthorInfo_Text.pdf?la=en

\section{Manuscript version: Accepted Manuscript}

This is a PDF of an unedited manuscript that has been accepted for publication. The manuscript will undergo copyediting, typesetting and correction before it is published in its final form. Please note that during the production process errors may be discovered which could affect the content, and all legal disclaimers that apply to the journal pertain. 


\section{Middle Telychian (Llandovery, Silurian) graptolites and biostratigraphy of the Howgill Fells, England, based upon the collections of D.W.R. Wilson housed in the Lapworth Museum of Geology, University of Birmingham}

\section{David K. Loydell*}

School of the Environment, Geography and Geosciences, University of Portsmouth, Burnaby Road, Portsmouth PO1 3QL, UK

*Correspondence: david.loydell@port.ac.uk

Abbreviated title: Middle Telychian graptolites, Howgills

Abstract: Examination of D.W.R. Wilson's PhD graptolite collection from the Howgill Fells, housed in the Lapworth Museum of Geology, University of Birmingham, reveals a high diversity (23 species) of middle Telychian graptolites from the uppermost Streptograptus crispus and Streptograptus sartorius (and possibly lowermost Monoclimacis griestoniensis) biozones. The collections include the first British records of Pseudoplegmatograptus hexagonalis and Pristiograptus pergratus. The stratigraphical range of $P$. pristinus is extended upwards, into the sartorius Biozone. One specimen of Stimulograptus clintonensis shows remarkable dorsal rhabdosome curvature proximally. Torquigraptus is particularly diverse in the sartorius Biozone with at least six species present: one new species, $T$. wilsoni, is described and two probable new species, one of which is very similar to the lower Telychian T. cavei, are left in open nomenclature.

The graptolites of the Howgill Fells of Cumbria have been the subject of numerous published stratigraphical and taxonomic studies (e.g. Rickards 1965, 1967, 1970, 1973; Rickards \& Woodcock 2005). Those from the middle Telychian (upper Llandovery), however, have received much less attention, largely because Rickards' PhD thesis work (which formed the basis of his earlier publications) focused much less on the part of the Howgills succession that had been studied in detail by D.W.R. Wilson (1954) during his PhD research. Fortunately, some of Wilson's collections remain in the Lapworth Museum of Geology's collections at the University of Birmingham (specimen numbers prefixed BIRUG: $\mathrm{BU}$ ) and these form the basis of this paper.

Wilson (1954) measured and described seven sections in considerable detail, with records of individual beds down to $1 / 8$ " (c. $3 \mathrm{~mm}$ ) thick. Wilson's graptolite collections from five of these localities (shown in Fig. 1) were available for study. Very usefully, he had painted locality and horizon numbers onto the graptolite-bearing slabs and these are cross-referenced in the Appendix to his thesis. The available material ( 52 graptolitic slabs) is from the highest bed within the Streptograptus crispus Biozone and from six of the seven graptolitic horizons above the last appearance of Streptograptus crispus. Wilson (1954) referred to his sections by letter $(\mathrm{a}-\mathrm{g})$ and the same lettering system is used in the text below, in Figure 1 and the figure captions to Figures 3-6. Detailed locality maps and descriptions of the sections are present in Wilson's thesis, to which the reader is referred. The five sections from which graptolite collections have been studied for the present paper are: (a) Hebblethwaite Hall Gill (from National Grid Reference SD 68819293 to SD 6910 9318); (b) Rawthey Birksfield Beck, SD 69139493 to SD 6916 9510; (c) Rawthey - Wards Intake, SD 71609732 to SD 7165 9739; (d) Rawthey - Mouth of Wandale Beck, SD 70749775 to SD 7085 9780; and (e) Wandale 
Hill, section starting at SD 7045 9795. Of these, Hebblethwaite Hall Gill was considered to be 'the best [section] in the district from the point of view of the present work' such that 'a full sequence from the turriculatus-zone to the base of the Wenlock can be measured.'

Fourteen graptolitic horizons (labelled in ascending stratigraphical order F14-F1), commencing in the crispus Biozone and extending over a stratigraphical thickness of $16^{\prime} 11^{\prime \prime}(5.15 \mathrm{~m})$, were identified in Hebblethwaite Hall Gill (Fig. 2). Some of these had distinctive lithological characteristics (e.g. interbedded volcanic material) and most were identifiable in all of the other sections studied, although Wilson noted that Beds F4, F2 and F1 were not developed in sections (d) and (e) which had a much lesser stratigraphical thickness, approximately half that of (a). This he attributed to the existence a submarine ridge in the area of (d) and (e) at the time of deposition (see also Rickards 1989, fig. 89). As can be seen from Figure 2, less than $15 \%$ of the thickness of strata exposed in the Hebblethwaite Hall Gill section is graptolitic, a typical feature of British Telychian sections (Zalasiewicz 1990, fig. 1), with interbedded strata being bioturbated mudstones deposited under oxic bottom water conditions and volcanic deposits (including numerous bentonites).

\section{Graptolite biostratigraphy}

The stratigraphical occurrences of Wilson's graptolites are shown on Figure 2 with all species illustrated in Figures $3-6$. In the captions for these the $F$ horizon and section from which the graptolites were collected is indicated. A list of species identified from each locality and horizon is provided in the Appendix.

As long as the highly distinctive Streptograptus crispus (Lapworth, 1876) is present, recognising the crispus Biozone is very straightforward and Wilson (1954) was able to place the lower seven of his graptolitic F horizons (F14-F8) confidently in this biozone. Above the last appearance of $S$. crispus, however, assigning graptolitic strata to a biozone becomes more challenging. The traditional Telychian biozonation had the crispus Biozone succeeded by the Monoclimacis griestoniensis Biozone (see e.g. Rickards 1976), but in the Howgills, as in Wales (Zalasiewicz 1994) and Estonia (Loydell et al. 1998), there is an interval between these biozones that lacks both S. crispus and Mcl. griestoniensis (Nicol, 1850). Zalasiewicz (1994) referred this to the Streptograptus sartorius Subzone (as the uppermost subzone of the crispus Biozone), but it was subsequently afforded biozonal status (e.g. Loydell et al. 1998; Zalasiewicz et al. 2009) on the basis that it represents strata deposited after the last appearance of $S$. crispus.

Wilson (1954) recorded S. sartorius from horizons F4 and F3 only and it seems reasonable to assign these two horizons to the sartorius Biozone. This leaves horizons F7-F5 unzoned; Wilson recorded only long-ranging taxa from them. Monoclimacis griestoniensis is not present in any of the post-crispus graptolitic horizons in the Howgills. Monoclimacis directa Zalasiewicz, Loydell \& Štorch, 1995, however, occurs from horizons F4 to F1. In Wales its first appearance precedes that of Mcl. griestoniensis (Zalasiewicz 1990), but its range extends into the lower part of the griestoniensis Biozone in which the biozonal index is rare and Mcl. directa is common. In the Ohesaare core, Estonia (Loydell et al. 1998) a single sample (from $370.70 \mathrm{~m}$ ) yielded Mcl. directa, S. sartorius and Spirograptus turriculatus (Barrande, 1850) (the last has never been recorded from the griestoniensis Biozone), with the succeeding sample (from $370.45-370.50 \mathrm{~m}$ ) containing a lower griestoniensis Biozone assemblage, including the biozonal index. It is clear therefore that the stratigraphical range of $\mathrm{Mcl}$. directa is from the sartorius Biozone to a level within the griestoniensis Biozone, but whether the highest Howgills graptolitic horizons represent the upper sartorius or lower griestoniensis 
Biozone is impossible to determine. The only other short-ranging species appearing within this interval is Torquigraptus pragensis (Priibyl, 1943), but this has a similar stratigraphical distribution to S. sartorius (i.e. sartorius to lower griestoniensis Biozone) so, unfortunately, its presence in F3, F2 and F1 does not resolve the issue. A conservative approach is adopted in Figure 2, with F14-F8 assigned to the crispus Biozone, F7-F5 left unzoned, F4 and F3 assigned to the sartorius Biozone and $\mathrm{F} 2$ and $\mathrm{F} 1$ to this biozone or the lower griestoniensis Biozone.

\section{Notes on graptolite species}

\section{Biserials}

Glyptograptus is represented by the diminutive G. nebula Toghill \& Strachan, 1970 (Figs 3A, F), originally described from the griestoniensis Biozone, and subsequently (e.g. by Hutt 1974) from lower in the Telychian (turriculatus and crispus biozones). Toghill \& Strachan (1970, p. 519) referred to the 'thin 'ghost-like' periderm' of the species which results in a clearly seen sicula and nema and these are seen in the flattened Howgills specimens (e.g. Fig. 3A). Toghill \& Strachan (1970) quoted a maximum rhabdosome width of $0.6 \mathrm{~mm}$; some of Hutt's specimens had a greater width $(0.75 \mathrm{~mm})$ and this is attained also by one of the Howgills specimens (Fig. 3F).

Wilson (1954) recognised that the distinctive features of the Petalograptus (now Parapetalolithus) material that he had were sufficient 'to justify its erection as a new variety or species.' Hutt (1974) encountered similar specimens in the Lake District and erected Petalograptus (now Parapetalolithus) wilsoni. One feature of the species is the twisted and expanded vane-like nematularium. A remarkable specimen in Wilson's collection (Fig. 3J) shows the growth of distal thecae around the nematularium and the thickening around the margins of the structure.

The most conspicuous of the retiolitids present is Retiolites angustidens Elles \& Wood, 1908 (Fig. 3B). The other identifiable retiolitid specimens are assigned to Pseudoplegmatograptus hexagonalis (Bouček and Münch, 1944), which, as its name suggests, possesses a reticulum largely formed of hexagons (Fig. $3 \mathrm{H}$ ). This is the first British record of this species. The more frequently recorded Pseudoplegmatograptus obesus (Lapworth, 1877) differs in having a more irregular reticular meshwork. Pseudoplegmatograptus elleswoodae (Bouček and Münch, 1944), first illustrated by Elles \& Wood (1908, text-fig. 224, pl. 34, fig. 13a, b), also possesses a hexagonal meshwork, but the individual hexagons are much larger than in Pse. hexagonalis.

\section{Uniserials}

The species of Streptograptus present include the two biozonal indices, S. crispus (Lapworth, 1876)(Fig. 3O) and S. sartorius (Törnquist, 1881)(Figs 3I, 4E). Both are well known (see e.g. Zalasiewicz 1994) and in the case of the latter, described also from superbly preserved chemically isolated material (Loydell \& Maletz 2004). Also in the collections are the ventrally (fish-hook) curved species, S. exiguus (Lapworth, 1876)(Fig. 3K) and the similar, but broader, S. loydelli Štorch \& Serpagli, 1993 (Fig. 4C). The latter is subzonal index for the upper crispus Biozone (Zalasiewicz et al. 2009), but ranges into the griestoniensis Biozone from which it was originally described.

Three species of Pristiograptus are present. A proximal end of $P$. bjerringus (Bjerreskov, 1975)(Fig. 3L) shows this species' characteristic rapid increase in dorso-ventral width. Originally described from the turriculatus Biozone, the stratigraphical range of this species has been extended 
recently into the crispus Biozone (Walasek et al. 2018) and it is from this biozone that the Howgills specimen originates. Most of Wilson's specimens of Pristiograptus belong to P. pristinus Pribyl, 1940 (Fig. 3M, N). This is a long-ranging species, first appearing in the upper Aeronian (Loydell 1993). The Howgills specimens represent the stratigraphically youngest record, extending the top of the species' range from the turriculatus Biozone to the sartorius Biozone. Another species recorded from Britain for the first time is P. pergratus Pribyl, 1940 (Fig. 3C), which matches very closely the type material of this species from the crispus Biozone of the Czech Republic. The single Howgills specimen is from the highest graptolite band (F1). This apparently rare species has also been recorded from the crispus-lower griestoniensis biozones of Latvia (Loydell et al. 2003).

Two well-known species of Monograptus are present: M. marri Perner, 1897 (Fig. 3D) and the more rapidly widening M. priodon (Bronn, 1835) (Fig. 4F). Although in Britain the stratigraphically highest confidently identified $M$. marri is stated to be from the turriculatus Biozone by Zalasiewicz et al. (2009), Rickards (1976) had recorded the species in Britain from as high as the griestoniensis Biozone, and Loydell et al. (1998) recorded and illustrated a specimen from the lower part of the griestoniensis Biozone of the Ohesaare core, Estonia. Stimulograptus is, as is typical of mid Telychian assemblages, represented by St. clintonensis (Hall, 1852) (Figs 4H, J, 5D), distinguishable from M. marri (and other species of Monograptus) by its non-overlapping thecae. Normally rhabdosomes of this species are straight or very nearly so, but two specimens on the same bedding plane from $\mathrm{F} 3$ show proximal dorsal curvature of an extent not previously recorded. In one specimen (Fig. 4J) there are $90^{\circ}$ of dorsal curvature (from th1-11) before the rhabdosome becomes straight; in the other (Fig. 4H) the curvature is less pronounced and affects fewer thecae (th1-8). Thecal morphology, rhabdosome dorso-ventral width and thecal spacing are as seen in 'normal' specimens of St. clintonensis and these specimens are assigned to this species but considered (particularly Fig. 4J) at the extremity of intraspecific variation.

Wilson (1954) recognised that his specimens of Monoclimacis (e.g. Fig. 3G) from the higher graptolitic beds in his sections were intermediate in width between Mcl. griestoniensis (Nicol, 1850) and Mcl. crenulata (Elles \& Wood, 1911). Zalasiewicz et al. (1995) revised a number of Telychian Monoclimacis species and erected a new species, Mcl. directa, for this species. It has been recorded also from central Wales (Zalasiewicz 1994), Estonia (Loydell et al. 1998) and Australia (Rickards and Jell 2002).

With the exception of the highly distinctive T. pragensis (Pribyl, 1943) (Figs 4I, 5B), the most challenging uniserial Telychian graptolites to identify are those belonging to Torquigraptus. In part, this is because there have been only a few detailed studies (e.g. Zalasiewicz 1994; Štorch 1998). There are also the problems that (1) many Torquigraptus species exhibit a considerable amount of intraspecific variation (see e.g. T. tullbergi in Štorch 1998 and T. obtusus in Loydell et al. 2015); (2) torsion of the rhabdosome axis can result in thecal details being obscured or unusually distorted or accentuated upon diagenetic flattening; and (3) there are strong similarities between a number of species. As a result it is frequently not possible to identify fragmentary specimens to species level.

Torquigraptus australis Štorch, 1998 is represented by a single specimen (Fig. 5A) showing the gradual increase in dorso-ventral width along the gently dorsally curved proximal part of the rhabdosome and distal spiralling. Similarly, there is only a single specimen, a proximal end (Fig. 4G), of Torquigraptus proteus (Barrande, 1850), a species that first appears in the turriculatus Biozone, but which occurs also in higher biozones, e.g. in the crispus-griestoniensis biozones in Bohemia (Štorch 1994). The Howgills specimen matches very closely material from the species' type locality, Litohlavy in Bohemia. A distinctive new species, T. wilsoni, is described below. 
Torquigraptus cavei Loydell, 1993 is a species recorded from the lower Telychian (upper guerichi and lowermost turriculatus biozones). A remarkably similar species (Figs 4B, 5C, F) occurs in horizon F3 at three Howgills localities ((b), (c) and (e)). None of the specimens possesses a proximal end so it is uncertain how long the narrow proximal part of the rhabdosome is, but all show the rapid increase in dorso-ventral width at the point where rhabdosome curvature becomes more pronounced that is typical of $T$. cavei; measurements (dorso-ventral width and thecal spacing) also are similar. The main difference between these Howgill specimens and $T$. cavei is the narrower bases to the thecae in the region of maximum rhabdosome curvature. They are assigned here to $T$. aff. cavei, a reflection of their similarity to but not conspecificity with this earlier Telychian species. This is a good example of iterative evolution and emphasizes that considerable caution should be adopted when identifying Torquigraptus species and using them biostratigraphically. Finally, a single specimen (Fig. 4D), again from horizon F3, resembles T. spiraloides (Pribyl, 1945) in rhabdosome and thecal morphology, but is narrower (maximum dorso-ventral width of figured specimen is $1.05 \mathrm{~mm}$ at a level within the rhabdosome at which it would be $1.4 \mathrm{~mm}$ in $T$. spiraloides). It is referred here to $T$. aff. spiraloides. There are therefore at least six species of Torquigraptus within the sartorius Biozone of the Howgills.

In addition to these various Torquigraptus species, Wilson's collection includes specimens of another strongly dorsally curved uniserial graptolite, assigned by Zalasiewicz (1994) to Monograptus (presumably sensu lato). Zalasiewicz's material of 'M.' pseudocommunis comprised threedimensional internal moulds with apparently fairly simple, hooked, symmetrical thecal apertures. The flattened Howgills specimens (Fig. 4A, 5E) suggest greater thecal apertural complexity but confident assignment to a genus probably must await examination of chemically isolated material. Zalasiewicz (1994) had limited material (eight specimens) of his new species, and with all specimens being proximal ends/fragments, the rhabdosome was described as 'short'. Most of the Howgill specimens are proximal ends, very similar to the type material (e.g. Fig. 4A). There are also, however, much more fully developed rhabdosomes (Fig. 5E) that exhibit both torsion of the rhabdosome axis and that the overall rhabdosome morphology is much less similar to that of Campograptus communis (Lapworth, 1876), to which ' $M$.' pseudocommunis was originally compared (Zalasiewicz 1994), resembling much more that of Oktavites.

\section{Systematic Palaeontology}

Genus Torquigraptus Loydell, 1993

Torquigraptus wilsoni sp. nov. (Fig. 6A-F)

Holotype. BIRUG: BU5638 (Fig. 6F), from Horizon F3, Streptograptus sartorius Biozone, Rawthey Wards Intake section, Howgill Fells.

Material. Seven specimens, all from Horizon F3, Streptograptus sartorius Biozone: six from the Rawthey - Wards Intake section and one from Wandale Hill. All are flattened.

Derivation of name. After the collector of the material, D.W.R. Wilson.

Diagnosis. Torquigraptus with rhabdosome forming a low initially dorsally curved helical spiral exhibiting sharp torsion of the rhabdosome axis above th5 or th6.

Description. Rhabdosomes comprise between one and one-and-a-half whorls of what appears originally to have been a low helical spiral. Dorsal curvature is maintained proximally despite the 
rhabdosome axis twisting sharply above th5 or th6. Further torsion of the rhabdosome axis results in thecal details being obscured. Parts of the narrow sicula are visible in three specimens, but in none is it well enough preserved for accurate measurement of its length. Thecae are triangular throughout, being axially elongated proximally. The thecal aperture is twisted to the reverse side of the rhabdosome. Theca 1 is not well enough preserved to be measured, but dorso-ventral width (DVW) thereafter increases rapidly: it is $0.35 \mathrm{~mm}$ at th2, $0.4 \mathrm{~mm}$ at th 3 and $0.7 \mathrm{~mm}$ at th5. The maximum DVW at th13 or th14 is slightly in excess of $1.0 \mathrm{~mm}$. 2TRD decreases from $1.8 \mathrm{~mm}$ at th 3 to $1.45-1.7$ $\mathrm{mm}$ in thecae distal to the point of rhabdosome torsion (i.e. distal to th5 or th6).

Remarks. The rhabdosome morphology proximally is reminiscent of that of some specimens of Oktavites contortus (Perner, 1897), a species known from the upper Aeronian and lower Telychian. That species, however, has more complex, laterally expanded thecae (Hutt et al. 1970; Loydell \& Zhao 1990) and a more tightly spirally curved rhabdosome (e.g. Loydell et al. 2015, fig. 19D). There are no similar species of Torquigraptus.

Acknowledgements I thank Jon Clatworthy of the Lapworth Museum of Geology, University of Birmingham for tracking down and loaning D.W.R. Wilson's graptolite collection. The original submission benefited from the constructive reviews of Mike Melchin and an anonymous reviewer.

Funding This research received no specific grant from any funding agency in the public, commercial, or not-for-profit sectors.

Appendix Listed here are localities, fossiliferous horizons and the fossils identified from these. Biserial graptolites are listed first, followed by uniserial graptolites, in alphabetical order, followed by other fossils.

a) Hebblethwaite Hall Gill

F6: Parapetalolithus wilsoni, Cochlograptus veles, Monograptus marri

(b) Rawthey - Birksfield Beck

F3: Monoclimacis directa, Monograptus marri, M. priodon, 'M.' pseudocommunis, Stimulograptus clintonensis, Streptograptus sartorius, Torquigraptus aff. cavei

(c) Rawthey - Wards Intake.

F1: Glyptograptus nebula, Retiolites angustidens, Monoclimacis directa, Pristiograptus pergratus, Streptograptus exiguus, S. loydelli, Torquigraptus pragensis

F2: Monoclimacis directa, Stimulograptus clintonensis, Torquigraptus pragensis 
F3: Pseudoplegmatograptus hexagonalis, Monoclimacis directa, Monograptus marri, M. priodon, 'M.' pseudocommunis, Pristiograptus pristinus, Streptograptus sartorius, Stimulograptus clintonensis, Torquigraptus australis, $T$. aff. cavei, $T$. pragensis, $T$. aff. spiraloides, $T$. wilsoni sp. nov., conodont F4: Monoclimacis directa, Monograptus priodon, Streptograptus sartorius, Torquigraptus proteus F7: Parapetalolithus wilsoni, Monograptus priodon, Pristiograptus pristinus, Torquigraptus sp. indet.

F8: Glyptograptus nebula, Pseudoplegmatograptus hexagonalis, Pristiograptus bjerringus, Stimulograptus clintonensis, Streptograptus loydelli

(d) Rawthey - Mouth of Wandale Beck

F3: Parapetalolithus wilsoni, Monoclimacis directa, Pristiograptus pristinus?, Stimulograptus clintonensis, Streptograptus sartorius

F8: Glyptograptus nebula, Cochlograptus veles, Monograptus sp. indet., Stimulograptus clintonensis, Streptograptus crispus, S. loydelli, Aptychopsis

(e) Wandale Hill

F3: Pseudoplegmatograptus hexagonalis, Monoclimacis directa, Monograptus marri, M. priodon, 'M.' pseudocommunis, Pristiograptus pristinus, Streptograptus sartorius, Stimulograptus clintonensis, Torquigraptus aff. cavei, T. wilsoni

Scientific editing by

\section{References}

Barrande, J. 1850. Graptolites de Bohême. Prague, 74 pp., 4 pls.

Bjerreskov, M. 1975. Llandoverian and Wenlockian graptolites from Bornholm. Fossils and Strata, 8, 1-94, pls 1-13.

Bouček, B. \& Münch, A. 1944. Retioliti středoevropského Llandovery a spodního Wenlocku. Rozpravy II. Trídy České Akademie, 53(41), 1-54.

Bronn, H.G. 1835. Lethaea Geognostica. 1. Schweizerbart, Stuttgart.

Elles, G.L. \& Wood, E.M.R. 1908. A monograph of British graptolites. Part 7. Monograph of the Palaeontographical Society, 62(305), 273-358, pls 32-35.

Elles, G.L. \& Wood, E.M.R. 1911. A monograph of British graptolites. Part 8. Monograph of the Palaeontographical Society, 64(316), 359-414, pls 36-41.

Hall, J. 1852. Palaeontology of New York: Volume 2, containing descriptions of the organic remains of the Lower Middle Division of the New York System. C. Van Benthuysen, Albany.

Hutt, J.E. 1974. The Llandovery graptolites of the Lake District. Part 1. Monograph of the Palaeontographical Society, 128(540), 1-56, pls 1-10. 
Hutt, J.E., Rickards, R.B. \& Skevington, D. 1970. Isolated Silurian graptolites from the Bollerup and Klubbudden stages of Dalarna, Sweden. Geologica et Palaeontologica, 4, 1-23.

Lapworth, C. 1876. On Scottish Monograptidae. Geological Magazine (2), 3, 308-321, 350-360, 499507, 544-552, pls 10-13, 20.

Lapworth, C. 1877. On the graptolites of County Down. Proceedings of the Belfast Naturalists' Field Club, Appendix, 1876-77, 125-147, pls 5-7.

Loydell, D.K. 1993. Upper Aeronian and lower Telychian (Llandovery) graptolites from western midWales. Part 2. Monograph of the Palaeontographical Society, 147(597), 56-180, pls 2-5.

Loydell, D.K., Frýda, J. \& Gutiérrez-Marco, J.C. 2015. The Aeronian/Telychian (Llandovery, Silurian) boundary, with particular reference to sections around the El Pintado reservoir, Seville Province, Spain. Bulletin of Geosciences, 90, 743-794.

Loydell, D.K., Kaljo, D. \& Männik, P. 1998. Integrated biostratigraphy of the lower Silurian of the Ohesaare core, Saaremaa, Estonia. Geological Magazine, 135, 769-783.

Loydell, D.K., Männik, P. \& Nestor, V. 2003. Integrated biostratigraphy of the lower Silurian of the Aizpute-41 core, Latvia. Geological Magazine, 140, 205-229.

Loydell, D.K. \& Maletz, J. 2004. The Silurian graptolite genera Streptograptus and Pseudostreptograptus. Journal of Systematic Palaeontology, 2, 65-93.

Loydell, D.K. \& Zhao, Y-H. 1990. Studies of some monograptids using the scanning electron microscope. Acta Palaeontologica Sinica, 29, 331-336, pls 1-3.

Maletz, J., Ahlberg, P., Suyarkova, A. \& Loydell, D.K. 2014. Silurian graptolite biostratigraphy of the Röstånga-1 drill core, Scania - a standard for southern Scandinavia. GFF, 136, 175-178.

Nicol, J. 1850. Observations on the Silurian strata of the south east of Scotland. Quarterly Journal of the Geological Society of London, 6, 53-65.

Perner, J. 1897. Études sur les Graptolites de Bohême llième Partie. Monographie des Graptolites de L'Étage E. Section a. Prague.

Přibyl, A. 1940. O českých zástupcích monograptidů ze skupiny Pristiograptus nudus. Rozpravy II. Trídy České Akademie, 50(16), 1-14, pls 1, 2.

Přibyl, A. 1943. O několika nových graptolitech z českého a nemeckého siluru. Část II. Věstník Královské České Společnosti Nauk Tř́da Matematicko-Prírodovedecká, 6, 1-16, pls 1, 2.

Pribyl, A. 1945. The middle-European monograptids of the genus Spirograptus Gürich. Bulletin International de l'Académie Tchèque des Sciences, 45, 185-231, pls 1-11.

Richter, R. 1871. Aus dem thüringische Schiefergebirge. Zeitschrift der Deutschen Geologischen Gesellschaft, 23, 231-256.

Rickards, R.B. 1965. New Silurian graptolites from the Howgill Fells (northern England). Palaeontology, 8, 247-271.

Rickards, R.B. 1967. The Wenlock and Ludlow succession in the Howgill Fells (north-west Yorkshire and Westmorland). Quarterly Journal of the Geological Society of London, 123, 215-271. 
Rickards, R.B. 1970. The Llandovery (Silurian) graptolites of the Howgill Fells, northern England. Monograph of the Palaeontographical Society, 123(524), 1-108, pls 1-8.

Rickards, R.B. 1973. On some highest Llandovery red beds and graptolite assemblages in Britain and Eire. Geological Magazine, 110, 70-72.

Rickards, R.B. 1976. The sequence of Silurian graptolite zones in the British Isles. Geological Journal, 11, 153-188.

Rickards, R.B. 1989. Northern England. In: Holland, C.H. \& Bassett, M.G. (eds) A global standard for the Silurian System. National Museum of Wales Geological Series, 9, 116-131.

Rickards, R.B. \& Jell, J.S. 2002. New graptolite faunas from the Llandovery, lower Silurian of the Graveyard Creek Subprovince, Broken River region, Queensland, Australia. Proceedings of the Geologists' Association, 113, 111-120.

Rickards, R.B. \& Woodcock, N.H. 2005. Stratigraphical revision of the Windermere Supergroup (Late Ordovician-Silurian in the southern Howgill Fells, NW England). Proceedings of the Yorkshire Geological Society, 55, 263-285.

Štorch, P. 1998. New data on Telychian (Upper Llandovery, Silurian) graptolites from Spain. Journal of the Czech Geological Society, 43, 113-141.

Štorch, P. \& Serpagli, E. 1993. Lower Silurian graptolites from southwestern Sardinia. Bollettino della Società Paleontologica Italiana, 32, 3-57.

Toghill, P. \& Strachan, I. 1970. The graptolite fauna of Grieston Quarry, near Innerleithen, Peebleshire. Palaeontology, 13, 511-521.

Törnquist, S.L. 1881. Om några graptolitarter från Dalarne. Geologiska Föreningens i Stockholm Förhandlingar, 5, 434-445, pl. 17.

Walasek, N., Loydell, D.K., Frýda, J., Männik, P. \& Loveridge, R.F. 2018. Integrated graptoliteconodont biostratigraphy and organic carbon chemostratigraphy of the Llandovery of Kallholn quarry, Dalarna, Sweden. Palaeogeography, Palaeoclimatology, Palaeoecology, 508, 1-16.

Wilson, D.W.R. 1954. The stratigraphy and palaeontology of the Valentian rocks of Cautley (Yorks W.R.). Unpublished PhD thesis, University of Birmingham.

Zalasiewicz, J. 1990. Silurian graptolite biostratigraphy in the Welsh Basin. Journal of the Geological Society, London, 147, 619-622.

Zalasiewicz, J. 1994. Middle to late Telychian (Silurian: Llandovery) graptolite assemblages of central Wales. Palaeontology, 37, 375-396.

Zalasiewicz, J., Loydell, D.K. \& Štorch, P. 1995. A taxonomic revision of three mid-Telychian monoclimacids. Journal of Paleontology, 69, 961-967.

Zalasiewicz, J.A., Taylor, L., Rushton, A.W.A., Loydell, D.K., Rickards, R.B. \& Williams, M. 2009. Graptolites in British stratigraphy. Geological Magazine, 146, 785-850. 
Fig. 1. Graptolitic middle Telychian localities referred to in the text plotted on part of Rickards' (1967, pl. 12) geological map of the eastern Howgill Fells. Lithostratigraphy has been updated and is that used in Rickards \& Woodcock (2005). Sections are referred to using the locality names of Wilson (1954): (a) Hebblethwaite Hall Gill (from National Grid Reference SD 68819293 to SD 6910 9318); (b) Rawthey - Birksfield Beck, SD 69139493 to SD 6916 9510; (c) Rawthey - Wards Intake, SD 7160 9732 to SD 7165 9739; (d) Rawthey - Mouth of Wandale Beck, SD 70749775 to SD 7085 9780; and (e) Wandale Hill, section starting at SD 70459795.

Fig. 2. Graptolitic horizons in the middle Telychian of the Hebblethwaite Hall Gill section (modified from Wilson 1954). Plotted also are the occurrences of graptolites from all five Howgill sections from what remains of Wilson's PhD collection, housed in the Lapworth Museum of Geology's collections at the University of Birmingham.

Fig. 3. Graptolites from the middle Telychian of the Howgill Fells. Scale bar represents $10 \mathrm{~mm}$. A, F, Glyptograptus nebula Toghill \& Strachan, 1970, F8; A, BIRUG: BU5601, flattened specimen showing thin periderm, section (c); F, BIRUG: BU5606, section (d). B, BIRUG: BU5602, Retiolites angustidens Elles \& Wood, 1908, distal fragment, F1, section (c). C, Pristiograptus pergratus Pribyl, 1940, BIRUG: BU5603, F1, section (c). D, Monograptus marri Perner, 1897, BIRUG: BU5604, F6, section (a). E, Cochlograptus veles (Richter, 1871), BIRUG: BU5605, F8, section (d). G, Monoclimacis directa Zalasiewicz, Loydell \& Štorch, 1995, BIRUG: BU5607, F3, section (c). H, Pseudoplegmatograptus hexagonalis (Bouček and Münch, 1944), BIRUG: BU5608, F3, section (e). I, Streptograptus sartorius (Törnquist, 1881), BIRUG: BU5609, three-dimensionally preserved, F3, section (e). J, Parapetalolithus wilsoni (Hutt, 1974), BIRUG: BU5610, F7, section (c). K, Streptograptus exiguus (Lapworth, 1876), BIRUG: BU5611, F1, section (c). L, Pristiograptus bjerringus (Bjerreskov, 1975), BIRUG: BU5612, F8, section (c). M, N, Pristiograptus pristinus Přibyl, 1940, section (c); M, BIRUG: BU5613, F7; N, BIRUG: BU5614, F3. O, Streptograptus crispus (Lapworth, 1876); F8, BIRUG: BU5615, section (d).

Fig. 4. Graptolites from the middle Telychian of the Howgill Fells, section (c). Scale bar represents 10 mm. A, 'Monograptus' pseudocommunis Zalasiewicz, 1994, BIRUG: BU5616, F3. B, Torquigraptus aff. cavei Loydell, 1993, BIRUG: BU5617, F3. C, Streptograptus loydelli Štorch \& Serpagli, 1993, BIRUG: BU5618, F1. D, Torquigraptus aff. spiraloides (Přibyl, 1945), BIRUG: BU5619, F3. E, Streptograptus sartorius (Törnquist, 1881), BIRUG: BU5620, F3. F, Monograptus priodon (Bronn, 1835), BIRUG: BU5621, F7. G, Torquigraptus proteus (Barrande, 1850), BIRUG: BU5622, F4. H, J, Stimulograptus clintonensis (Hall, 1852), F3; H, BIRUG: BU5623; J, BIRUG: BU5625, specimen showing remarkable proximal dorsal rhabdosome curvature. I, Torquigraptus pragensis (Přibyl, 1943), BIRUG: BU5624, F1.

Fig. 5. Graptolites from the middle Telychian of the Howgill Fells. Scale bar represents $10 \mathrm{~mm}$. A, Torquigraptus australis Štorch, 1998, BIRUG: BU5626, F3, section (c). B, Torquigraptus pragensis (Přibyl, 1943), BIRUG: BU5627, F2, section (c). C, F, Torquigraptus aff. cavei Loydell, 1993, F3; C, BIRUG: BU5628, section (c); F, BIRUG: BU5631, section (e). D, Stimulograptus clintonensis (Hall, 1852), BIRUG: BU5629, distal thecae, F3, section (e). E, 'Monograptus' pseudocommunis Zalasiewicz, 1994, BIRUG: BU5630, F3, section (c).

Fig. 6. Torquigraptus wilsoni sp. nov., $F 3$, all except $D$ are from section (c). Scale bar represents 10 mm. A, BIRUG: BU5632; B, BIRUG: BU5633 and BU5634; C, BIRUG: BU5635; D, BIRUG: BU5636, section (e); E, BIRUG: BU5637; F, BIRUG: BU5638, holotype. 


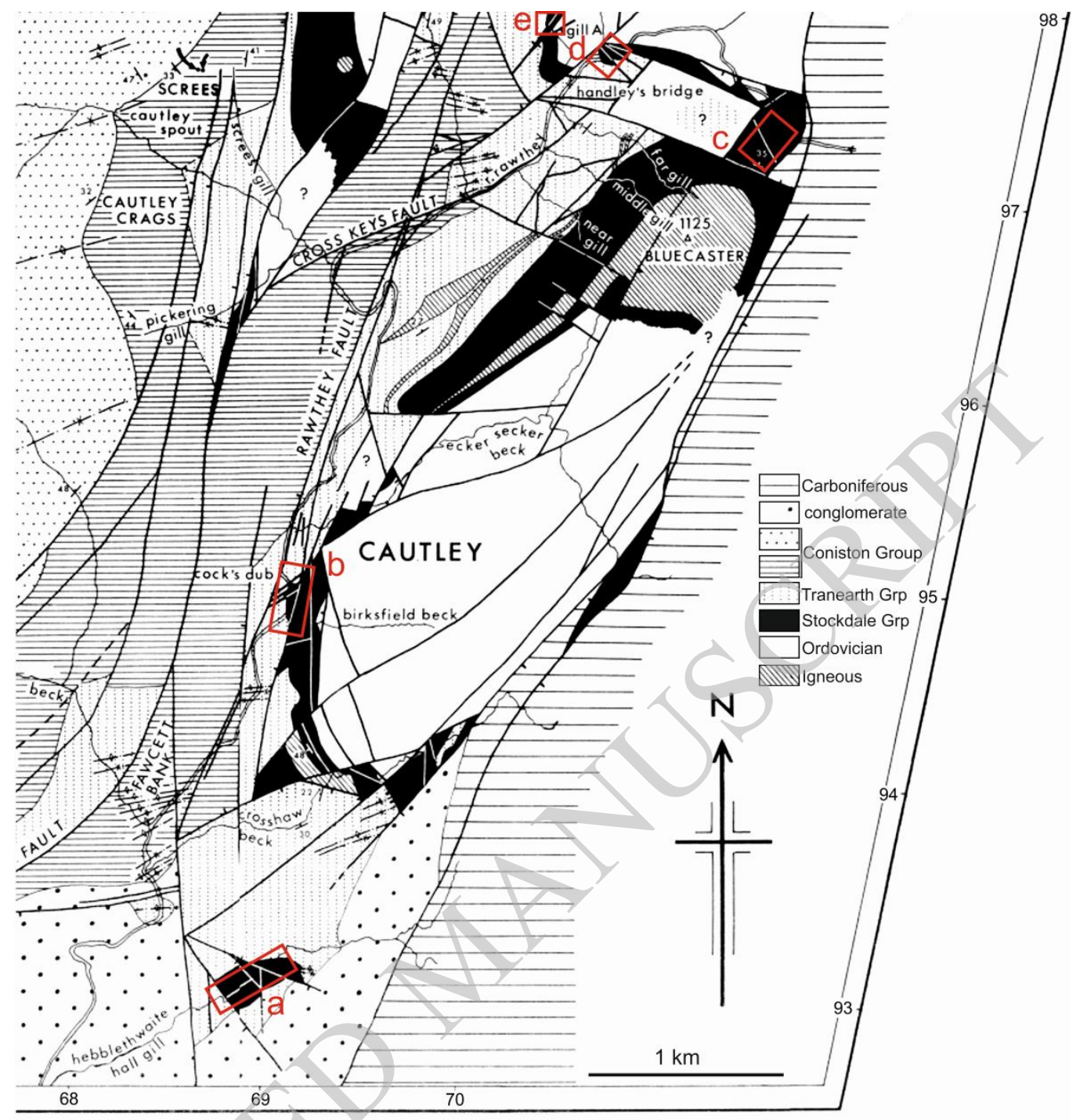




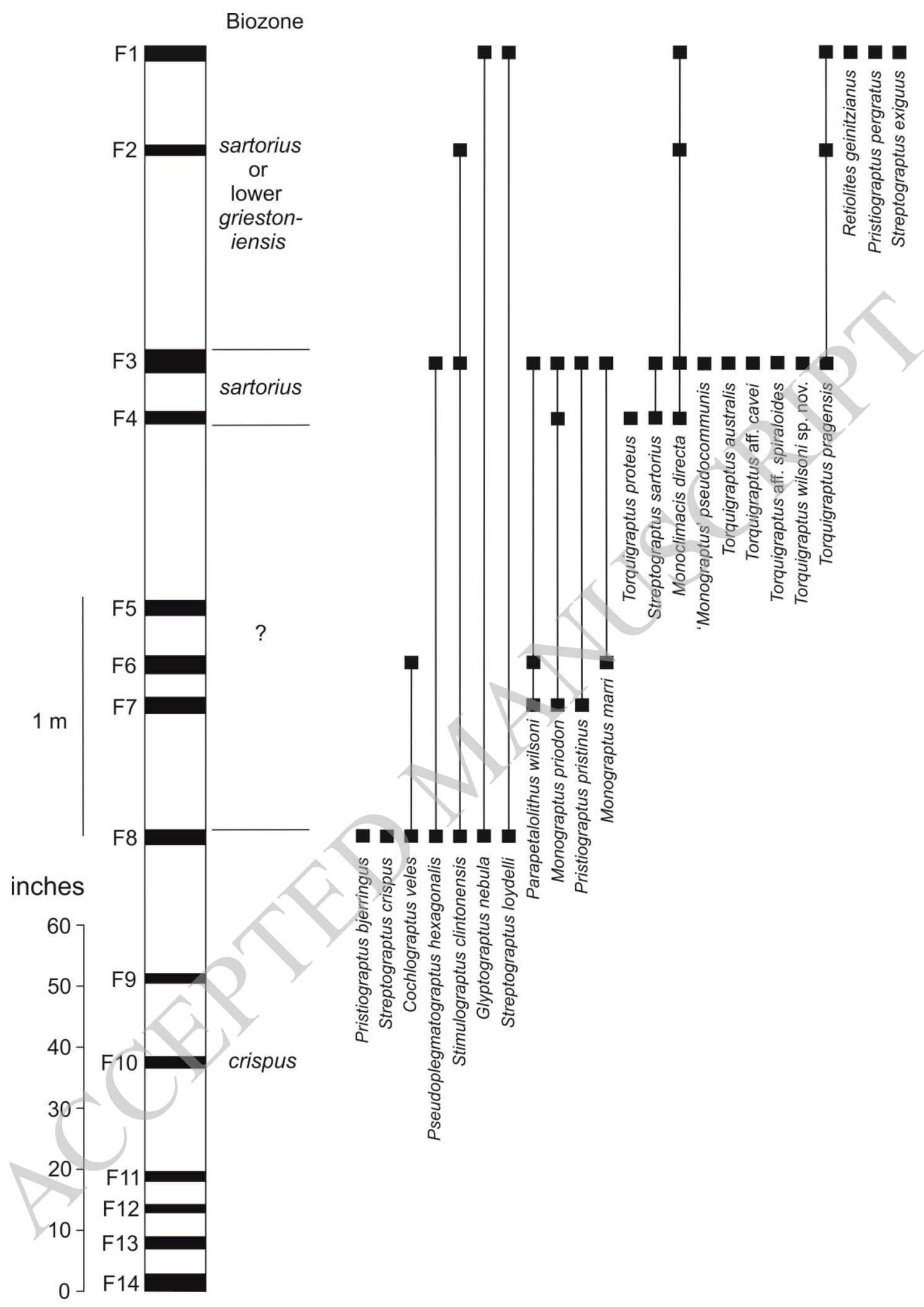




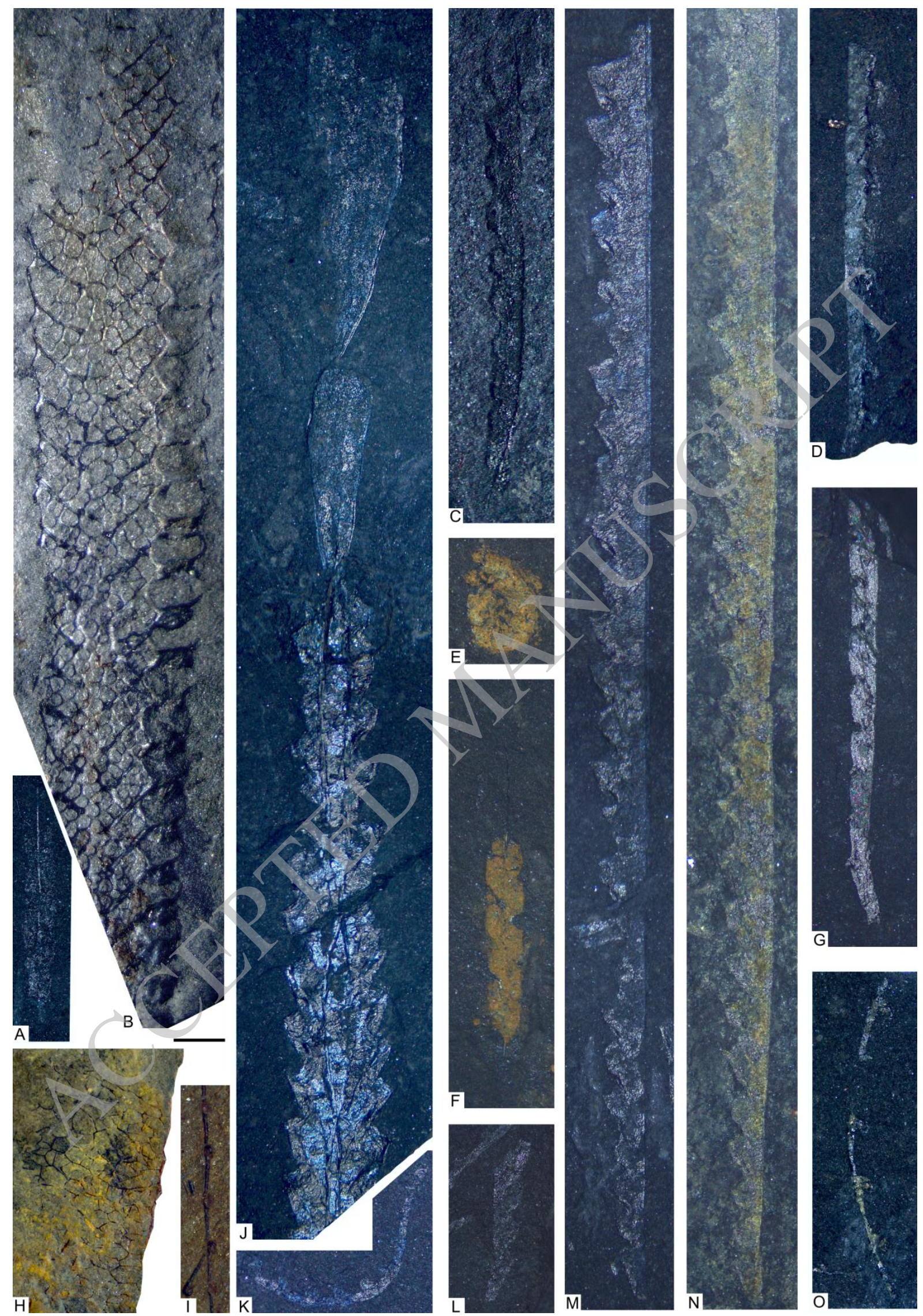




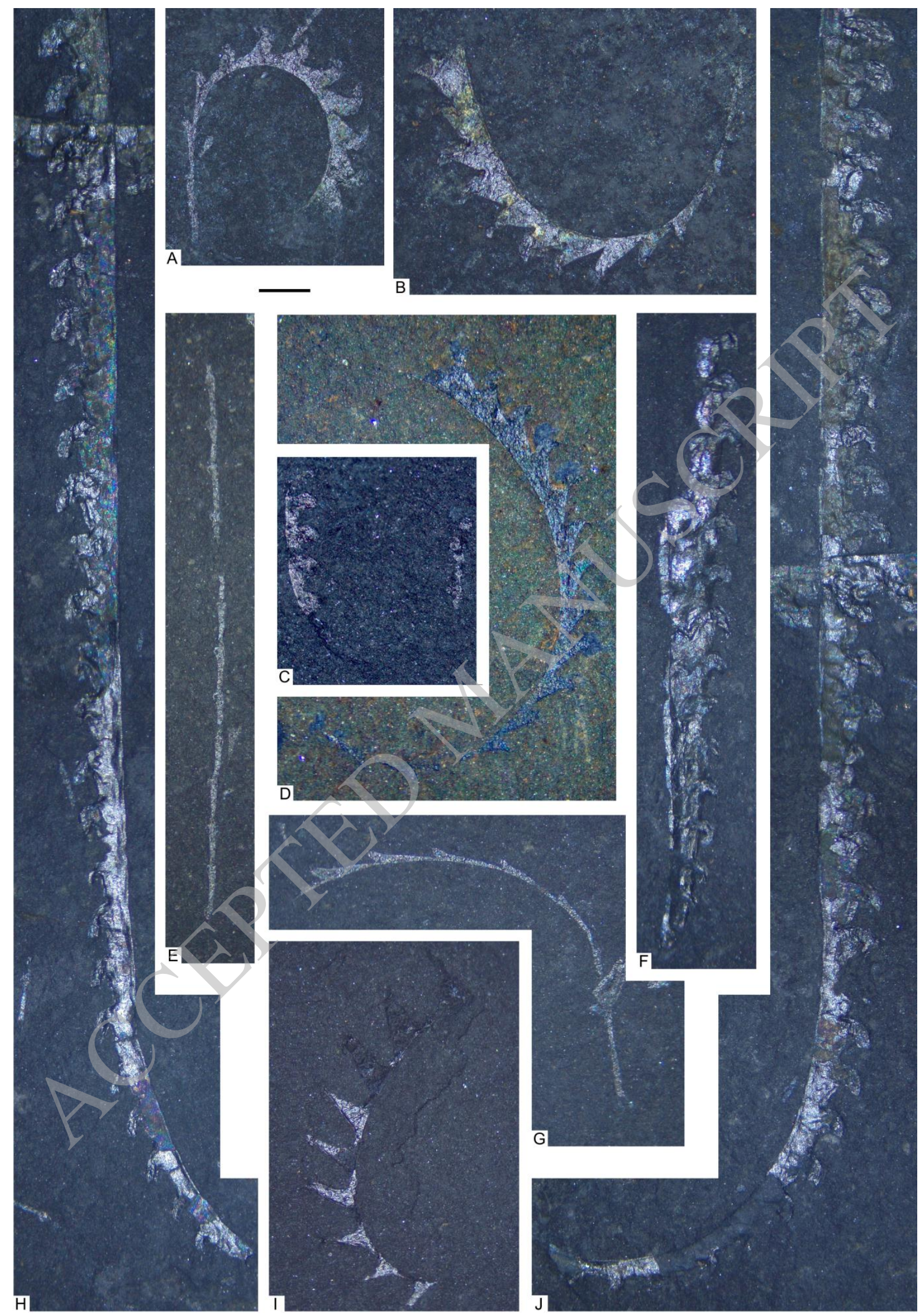



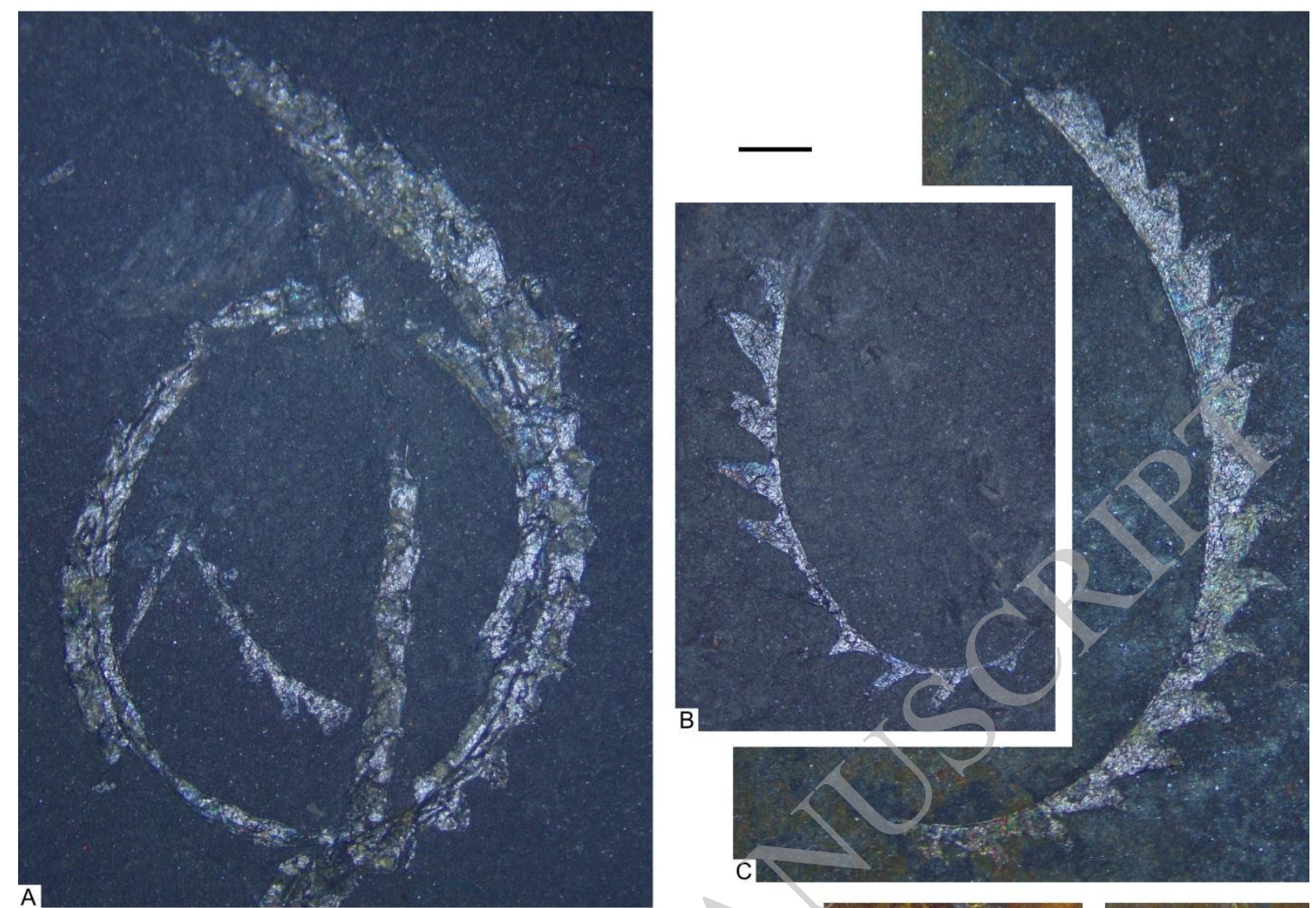

A
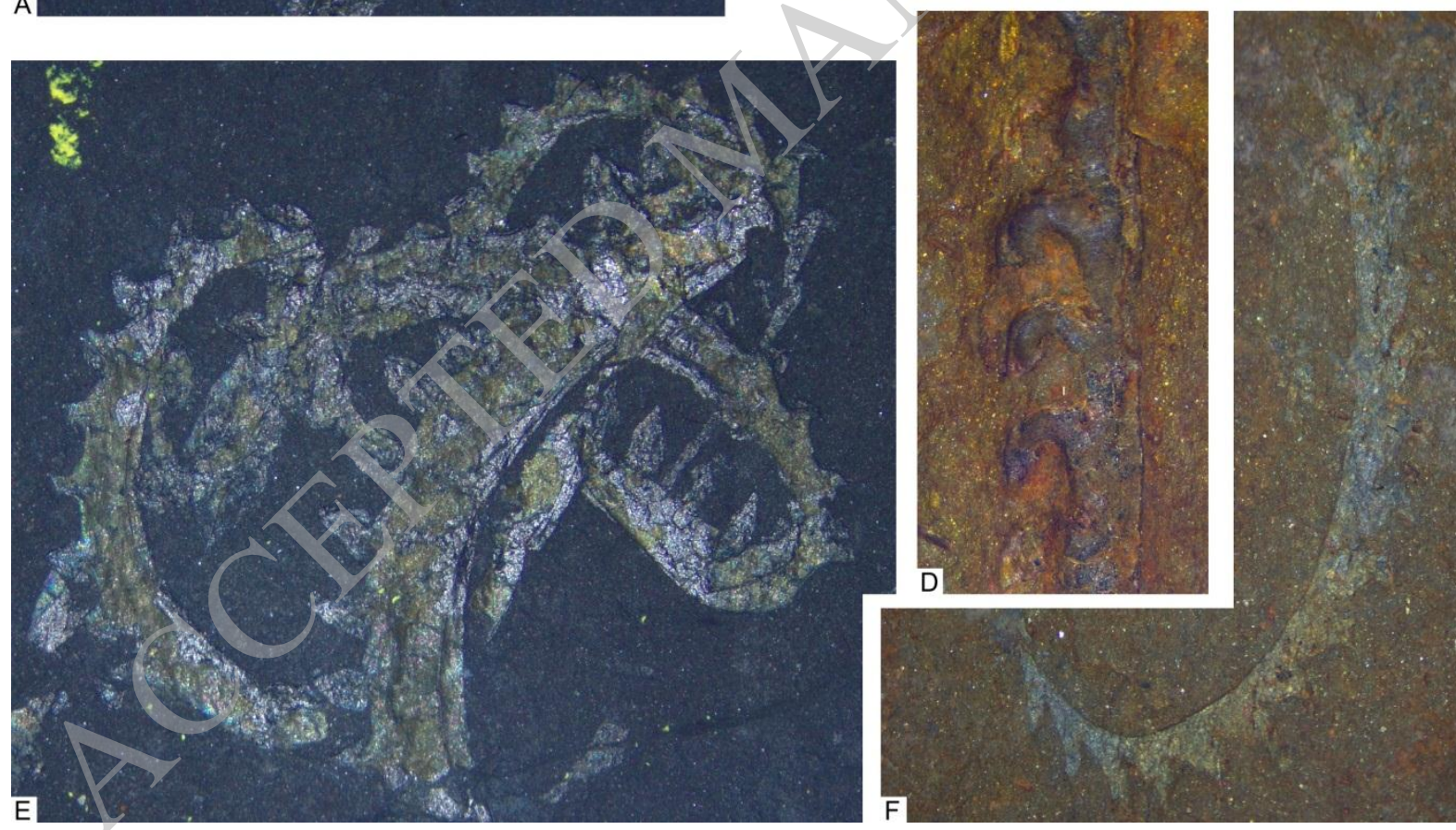

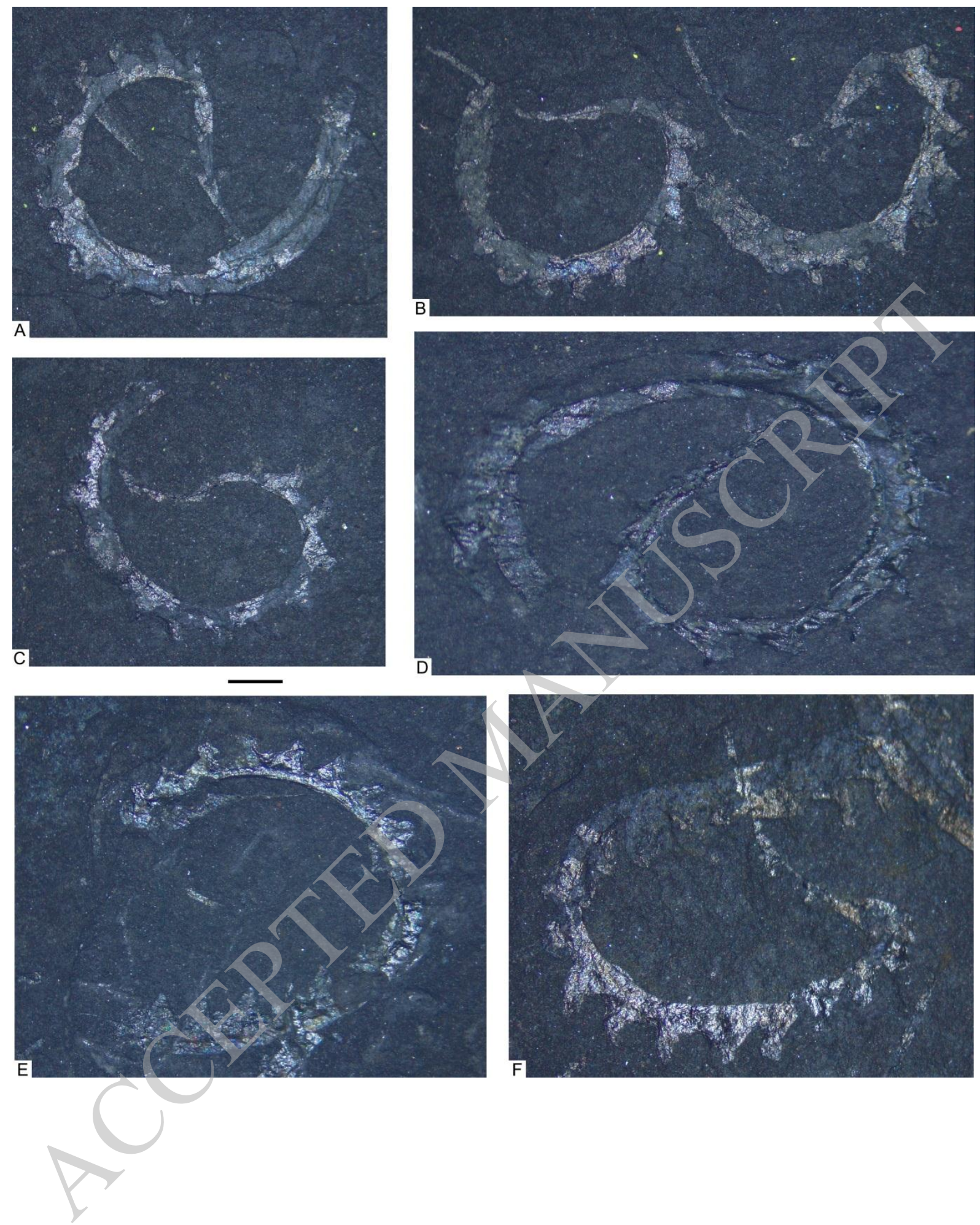